\title{
INVESTIMENTOS INTERNACIONAIS
}

\author{
Hugo Brazioli Slivinskis \\ Aluno do Curso de Graduação da Faculdade de Direito da Universidade de São Paulo
}

Resumo:

$\mathrm{O}$ artigo principia com a análise dos influxos de investimentos internacionais, e para tanto relaciona-os com o crescimento dos principais setores da economia brasileira, com os investimentos brasileiros e estrangeiros no país, com os fluxos de investimentos estrangeiros diretos e em portfólio, com os investimentos externos em moeda e com a captação de recursos externos.

Abstract:

This article begins with an analysis of international investments inflow, relating them to the growth of main sector of Brazilian economy, to brazilian and foreign investments in Brazil, to the foreign direct investments and portfolio investments, to foreign currency investments as well as to inflow of external resources.

Unitermos: caracterização dos fluxos de capitais; modalidades de investimentos.

Sumário:

a. Introdução.

b. Caracterização dos fluxos de capitais.

- Os fluxos de investimentos internacionais relacionados com o crescimento dos principais setores da economia brasileira.

- Os investimentos brasileiros e estrangeiros no País.

- O fluxo de investimentos estrangeiros diretos e em portifólio.

- Os investimentos externos em moeda.

- Captação de recursos externos.

c. Modalidades de Investimentos.

- Investimentos diretos.

- Investimentos em carteira ou portifólio.

- Fundos de renda fixa para o capital estrangeiro.

- Fundos de privatização. 
- Fundos de investimento imobiliário.

- Fundo de investimentos em empresas emergentes - FIEE.

- Outras formas de captação de recursos externos.

d. Importância dos investimentos estrangeiros.

e. O tratamento jurídico dos investimentos internacionais no Brasil.

- Conceito de investidor.

- As exceções à isonomia específica dos capitais estrangeiros.

- O registro do investimento.

- Proteção jurídica do investimento.

- $\mathrm{O}$ direito de expropriar.

a. Introdução.

Inicialmente o processo de industrialização estava restrito à economia nacional, tanto para a produção de bens de consumo quanto para a comercialização dos mesmos.' Com a crescente especialização e acumulação de capitais emergiu lentamente uma nova perspectiva de economia baseada principalmente na difusão de mercados $^{2}$ como princípio norteador do lucro, diversificação dos riscos e caráter assecuratório oligopolista.

A difusão de mercados principiou pelo comércio internacional de bens (importação e exportação), sendo seguida pelos movimentos de capitais, dos quais constitui modalidades o investimento direto e o investimento indireto ou Nonofficial, Long Term (Portfolio, Direct), Short Term, Official. ${ }^{3}$

1. Sobre o porquê da existência da comercialização entre paises ver a Teoria das Vantagens Comparativas, que em linhas gerais afirma que duas nações têm relações comerciais quando apresentam custos de produção diferentes. Montoro Filho, André Franco e outros. Manual de economia. Coordenadores: Diva Benevides Pinho, Marco Sandoval de Vasconcellos, $2^{\mathrm{a}}$ ed., São Paulo, Saraiva, 1992, p. 238.

2. World Investment Report, 1994. Transnational Corporations, Employment and the Workplace. United Nations. New York and Geneva, 1994.

3. International Factor Movements, p. 260. 
Nesse contexto de integração internacional econômica o processo de globalização foi inevitável e tendente a aprofundar cada vez mais a integração contínua entre empresas, mercados e Estados. ${ }^{4}$

A globalização abarca em si os beneficios de aumento de empregos e desenvolvimento de outros setores industriais, extrativos e agrícolas e os riscos de uma economia mundial porosa e interdependente - principalmente para os países de economias "emergentes"

Um exemplo dessa interdependência negativa, das economias, foram as consequiências da crise do Sudeste Asiático, que caracterizaram-se pelas mudanças bruscas da taxa de câmbio que levaram a perda de US\$2 trilhões, reduzindo a liquidez internacional, aumentando a aversão ao risco e expondo os países (como o Brasil) de regime cambial pouco flexível e extremamente valorizado, sistema financeiro desequilibrado, desajustes e dificuldades de financiamentos de contas externas, problemas de paralisia política e ativos sobrevalorizados ao ataque especulativo. $^{5}$

Atualmente o termo "globalização" conota mercados completamente integrados para bens, serviços e fatores de produção ${ }^{6}$ e pode-se dizer a princípio, sem no entanto incorrer em erro conceitual, que o nível de globalização dependerá em grande parte da política do país receptor dos investimentos. Um exemplo deste fato foi a classificação do Brasil, em 1993, entre os cinco países de maior risco (77\%), conforme foi divulgado pela revista de The Economist, que considerou os fatores endividamento, saldo no balanço de pagamentos e estabilidade, ou seja: quanto à política e as questões sociais. ${ }^{7}$ A título de exemplo, em novembro deste ano o IPC em São Paulo, apurado pela FIPE, foi de $35,84 \%$ e a legislação brasileira restringia à alíquota de $5 \%$ a dedução como despesa operacional do preço líquido de vendas de produto resultante de tecnologia importada, assim se a empresa tivesse que pagar $10 \%$ de royalties para o exterior só poderia deduzir $5 \%$ como despesa, o

4. Pode-se dizer inclusive, como afirma o promissor advogado penalista e dos direitos das comunicações Victor Gabriel de Oliveira Rodriguez, que “... o simbolo principal da globalização tem sido a evolução dos processos comunicativos"

5. Kandir, Antonio. Resposta do Brasil à crise.

6. World Investment Report 1994. Transnational Corporations, Employment and the Workplace. United Nations. New York and Geneva, 1994, p. 149.

7. Estado de São Paulo de 05.09.93 
que obviamente diminuía a transferência de tecnologia e o interesse dos investidores estrangeiros em investimentos diretos. ${ }^{8}$

Outro fato difícil de ser divorciado na análise da globalização é a presença das companhias transnacionais que, desde 1993, são responsáveis por quase metade das trocas internacionais. ${ }^{9}$

As companhias transnacionais (TNCs transnational companies) são empresas que operam em mais de um país beneficiando-se das patentes, trademarks, reputação e experiência administrativa na exploração da sua marca no mercado, utilizando-se de várias estratégias para aumentar o lucro ou para simplesmente assegurar o produto em mercado estrangeiro.

Dentre as estratégias de aumento do lucro temos a mundialização da produção que pode ocorrer em relação à totalidade das etapas que levam ao produto final ou a parte dessas etapas.

No primeiro caso tem-se as empresas que devido a expansão no mercado consumidor internacional apresentam custo menor em produzir no país estrangeiro do que realizar as constantes exportações, como por exemplo a Indústria Polti européia fabricante do Vaporetto que passou a vender mais no mercado brasileiro do que no mercado nativo, o que ocasionou um investimento direto de U\$ 15 milhões (60\% da matriz italiana) para montar uma filial no Brasil, fato que gerou mais de duzentos empregos diretos na região de Araras e uma perspectiva de exportação de $20 \%$ das vendas para outros países sul-americanos. ${ }^{10}$

Já no caso da mundialização, ocorre em cada país as etapas de produção mais adequadas aos recursos disponíveis e à política econômica vigente, como é o caso das indústrias automotivas, onde, por exemplo, o motor é francês, o freio é alemão e o chassi e a montagem são brasileiras.

Dois outros fatores que contribuem para a presença das TNCs em um país são a diversificação do risco e a proteção do produto no mercado internacional.

8. Ver posterior gráfico sobre o comportamento dos investimentos diretos e portifólio durante os anos de 1977 à 1997, apresentado no item irvestimentos diretos.

9. Vemon, Raymond. Research on transnational corporations: shedding old paradigms. Transnational Corporation, v. 3, n. 1, fev. 1994, p. 137.

10. Novais, Marcelo. Dinheiro a vapor. Dicas de Negócios, Oesp Midia Direta, RPM, ano 1, n. 7. 
Sobre o segundo tem-se a tese de Stephen Himer, " segundo a qual todo investidor no exterior é um monopolista ou um oligopolista quanto ao produto que investe em um mercado estrangeiro. O caráter monopolista levaria o investidor a desbravar novos mercados e o caráter oligopolista ocasionaria investimentos no mercado desbravado de produtos de alta elasticidade cruzada dos concorrentes do investidor pioneiro, assim, citando o professor doutor Luiz Olavo Baptista, "onde a Ford investir, a GM estaria investindo, onde a Shell investisse, a Exxon estaria presente" $^{12}$

Com a crescente interação entre mercados aumentou a importância da análise dos investimentos estrangeiros, especialmente os investimentos diretos, que têm sido uma das áreas de maior atenção na economia internacional da segunda metade do século XX, frente às preocupações da desnacionalização da economia e às necessidades de crescimento da economia que estas modalidades de investimentos proporcionam.

Assim, frente à realidade da dispersão dos mercados, pode-se distinguir entre dois meios de se suprir um mercado internacional: via exportação ou investindo na produção do país exportador. Somente a segunda contribui efetivamente no mercado suprido para geração de empregos, transferência de tecnologia, desenvolvimento de outros setores da economia e aportes expressivos de capitais, mas é extremamente dependente do regime de investimentos internacionais adotados pelo país.

Assim, é intuito do presente capítulo analisar os investimentos estrangeiros sobre a óptica do fluxo, modalidades, importância e tratamento pelo Brasil.

11. The International Operation of National Firms: A Study of Direct Foreign Investment, Cambridge, Mass.: MIT Press, 1976, passim apud Baptista, Luiz Olavo. Investimento internacionais no direito comparado e brasileiro - Porto Alegre: Livraria do Advogado, 1998, p. 25.

12. Baptista, Luiz Olavo. Investimentos internacionais no direito comparado e brasileiro - Porto Alegre: Livraria do Advogado, 1998, p. 25. 
b. Caracterização dos fluxos de capitais.

O presente item tem por objetivo documentar as principais tendências dos fluxos de investimentos estrangeiro no Brasil, fornecendo os subsídios necessários para que se possa entender, em linhas gerais, o impacto que o capital estrangeiro vem exercendo na economia brasileira.

- Os fluxos de investimentos internacionais relacionados com o crescimento dos principais setores da economia brasileira.

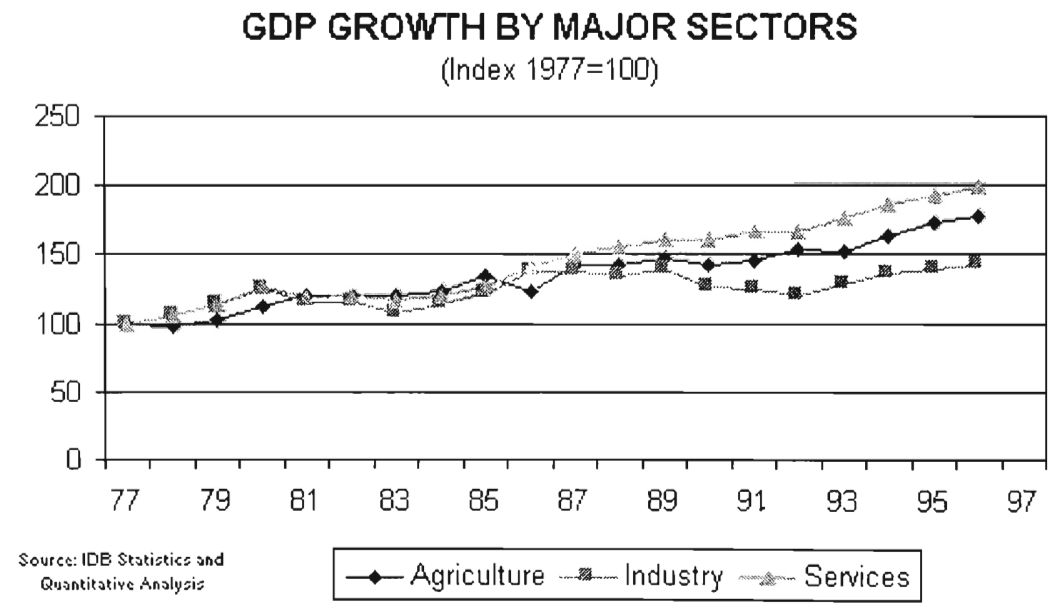

A globalização dos mercados traz a necessidade de operações financeiras globalizadas ("casas de títulos", corretoras, bancos de investimentos e bancos de negócios) $)^{13}$ e o desenvolvimento do setor de "serviços industriais" ${ }^{14}$

13. Barros, Octavio de. Estudo da competitividade da Indústria brasileira. Oportunidades abertas para o Brasil face aos fluxos globais de investimento de risco e de capitais financeiros nos anos 90. Bloco: Condicionantes internacionais de competitividade. Work Shop, Campinas, 1993, p. 45 .

14. Barros, Octavio de. Estudo da competitividade da Indústria brasileira. Oportunidades abertas para o Brasil face aos fluxos globais de investimento de risco e de capitais financeiros nos 
(controle e gerenciamento de atividade produtivas ou de outros serviços que tem por escopo diminuir o custo de produção de empresas).

Desta forma nota-se um aumento do crescimento do setor de serviços com os influxos do capital estrangeiro, o que demonstra o elemento central do processo de transnacionalização: "interpenetração patrimonial".

- Os investimentos brasileiros e estrangeiros no País.

Colocada a particularidade de que o mercado global cresce em investimentos nas áreas de serviços e que o Brasil tem acompanhado esta tendência, faz-se interessante registrar os investimentos brasileiros e estrangeiros realizados no País.

Esse registro far-se-á em duas etapas, a primeira demonstra os dados dos investimentos de 1992 a 1996 e a segunda os dados dos três últimos trimestres de 1996 com os três primeiros trimestres de $1997 .^{15}$

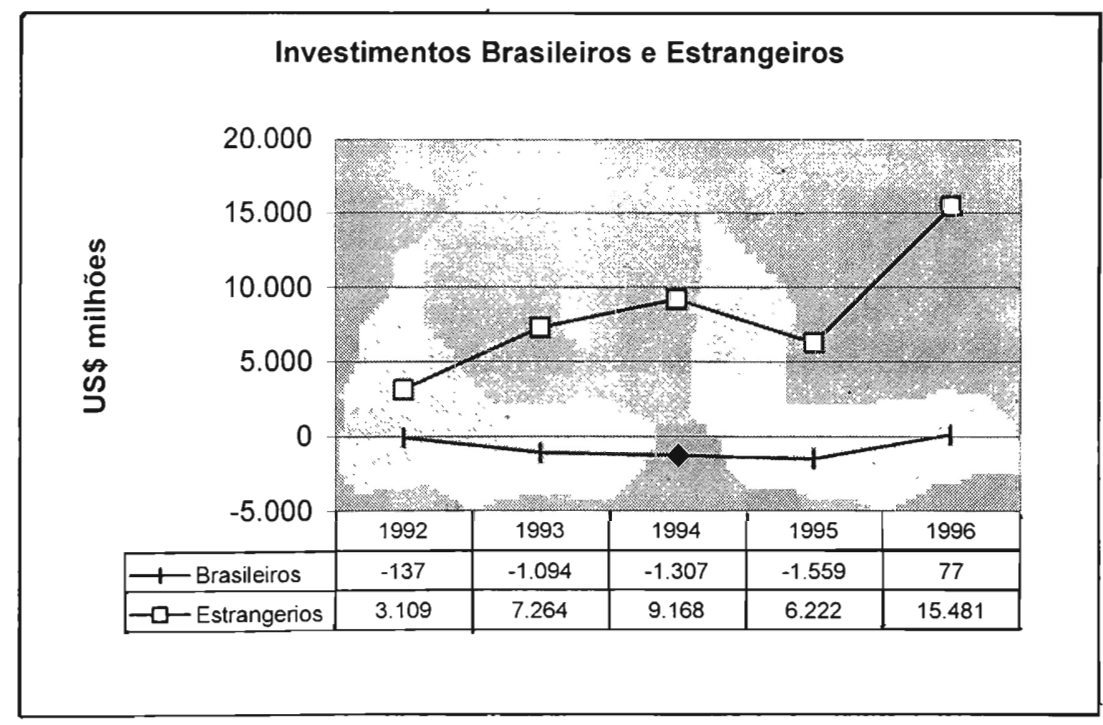

anos 90. Bloco: Condicionantes internacionais de competitividade. Work Shop. Campinas, 1993. p. 47.

15. Dados extraidos do Boletim do Banco Central. 


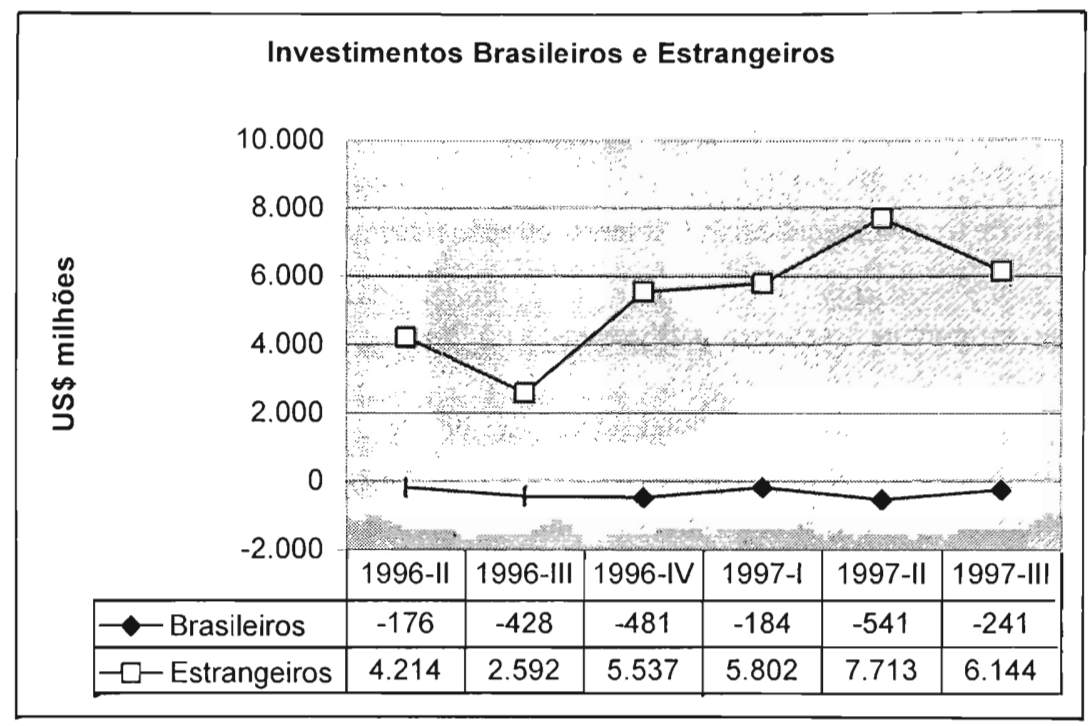

O fluxo de investimentos estrangeiros vêm-se apresentando constantemente superiores aos investimentos brasileiros, o que ocasiona uma atenção maior à destinação desses investimentos.

- O fluxo de investimentos estrangeiros diretos e em portifólio.

As modalidades mais importantes de investimentos são os investimentos diretos e os investimentos em portifólio, sendo que os últimos sofrem bruscas mudanças em decorrência de alterações macroeconômica-políticas, caracterizando-se por serem pouco estáveis. 


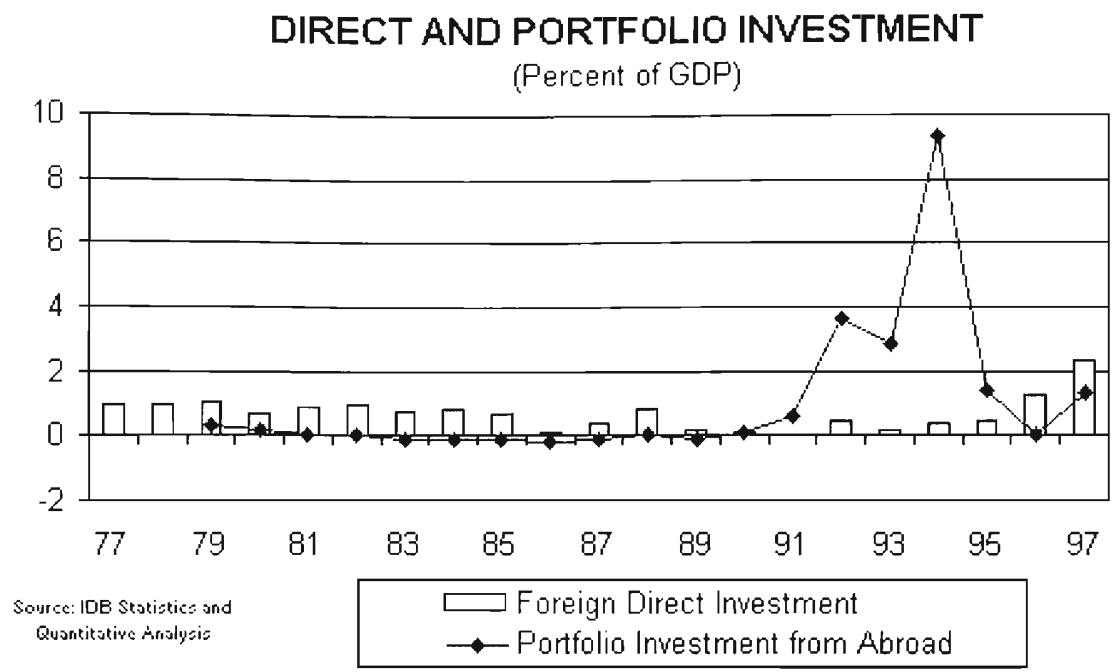

Esta instabilidade pode ser facilmente percebida no gráfico acima considerando a retirada brusca em 1995 dos investimentos em portifólio devido a uma crise financeira interna e a queda do crescimento da economia.

Assim, é imperioso observar a tendência desses investimentos externos no Brasil, a fim de questionar a estabilidade do crescimento econômico proporcionada por estes influxos externos.

Os primeiros dados que devem ser apresentados para se obter uma idéia geral são os que demostram a quantidade de capitais externos destinadas a essas duas modalidades. 


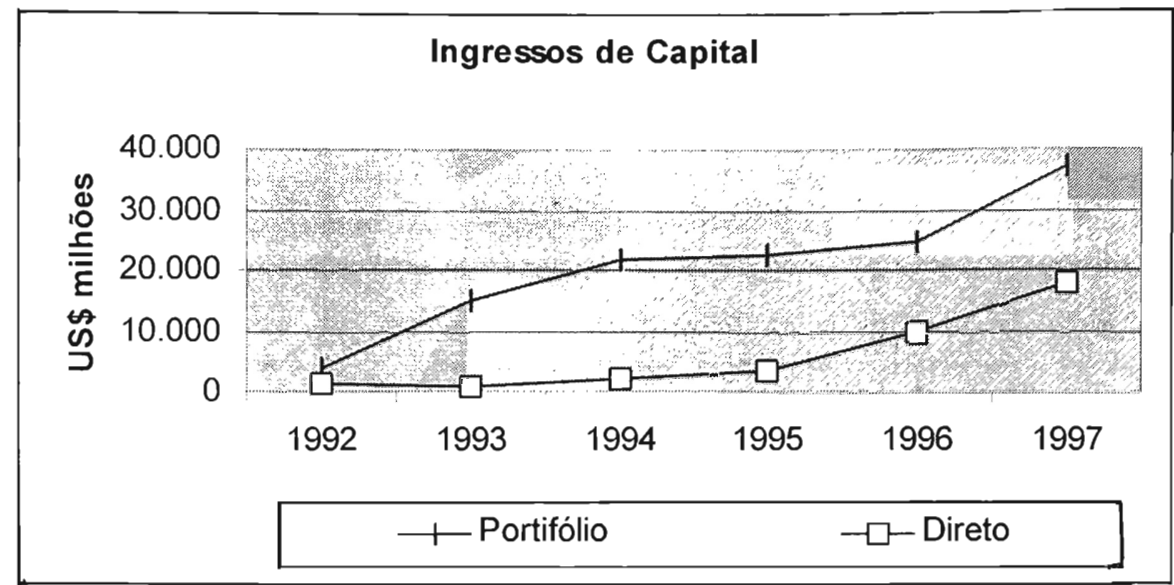

Pelo gráfico exposto percebe-se que os investimentos em portifólio são superiores aos investimentos diretos, no entanto não se pode a partir desses dados verificar um tendência de crescimento.

Desta forma, apresenta-se a seguir os crescimentos percentuais dos investimentos em portifólio e direto, a fim de se poder concluir sobre uma tendência de crescimento.

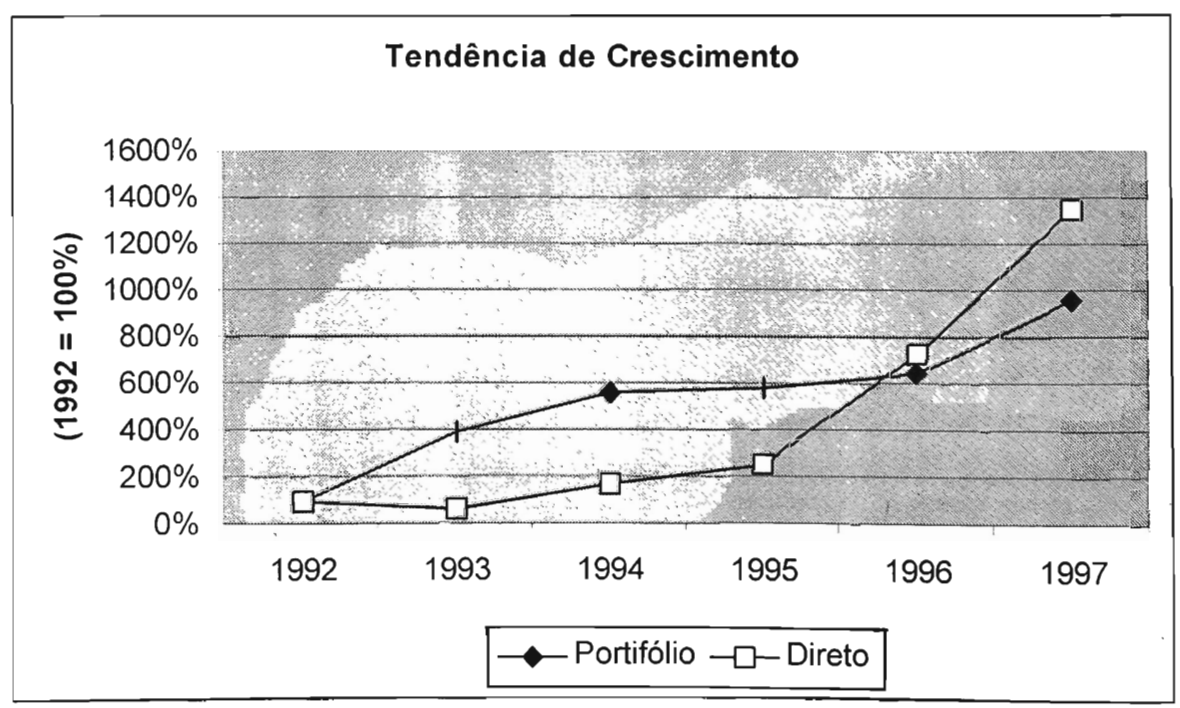




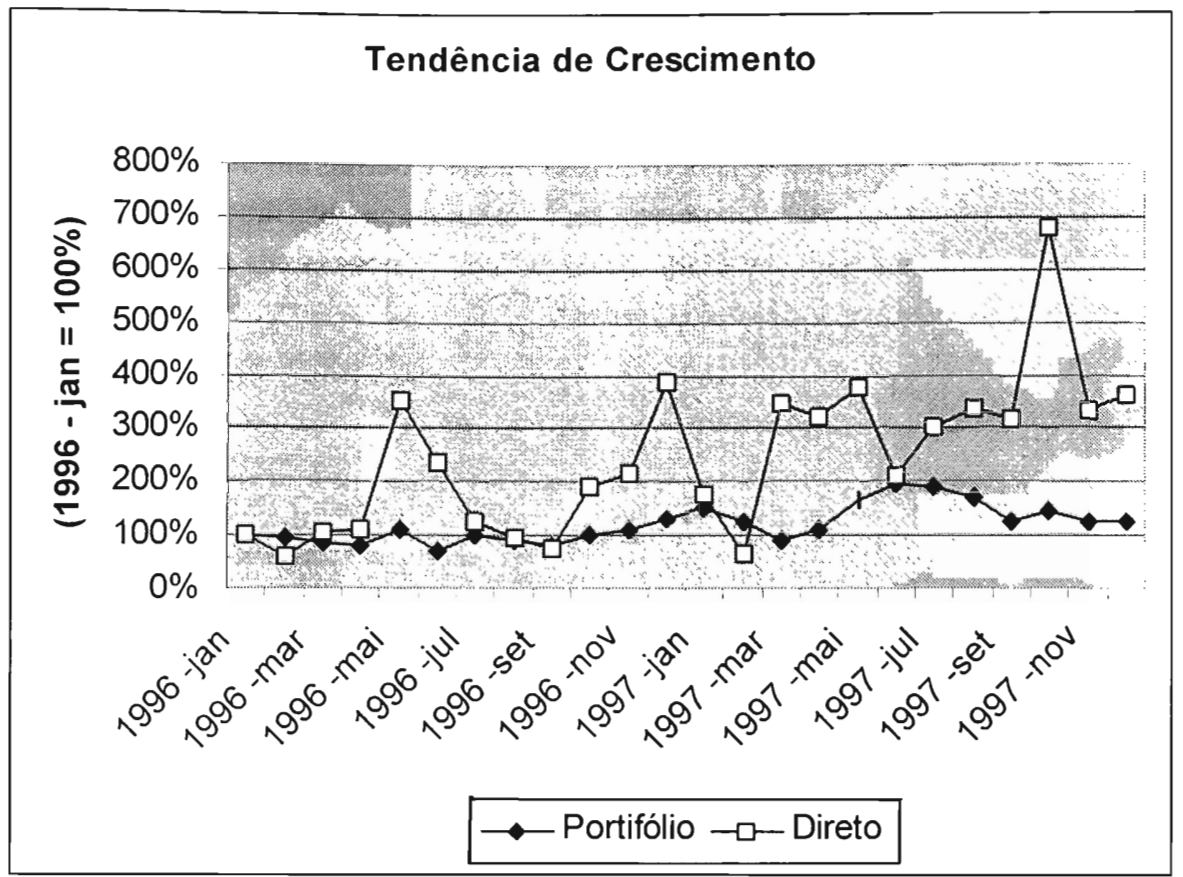

Desta forma pode-se perceber que ao longo dos anos a tendência de crescimento dos investimentos diretos sobre os investimentos em portifólio vem se acentuando, especialmente durante os dois últimos anos, possibilitando um crescimento econômico de maior estabilidade frente a crises bruscas.

Um fato atual que tem influenciado substancialmente - nos últimos dois anos ${ }^{16}$ o ingresso de investimentos diretos estrangeiros são as privatizações, que em 1997 constituíram 38,88\% dos investimentos diretos e em 1997, 34,06\%. ${ }^{17}$

Outros dados recentes do $\mathrm{PND}^{18}$ são a participação de $100 \%$ do capital estrangeiro na desestatização da Malha Oeste da Rede Ferroviária Federal e a participação de $61 \%$ (US\$ 1.384 milhões) no caso da Light. ${ }^{19}$

16. Em 1995 não houve participação do capital estrangeiro em programas de privatização.

17. BNDES/ Privatização - Moedas.

18. Empresas desestatizadas na forma da Lei n. 8.031 de 12.04.90.

19. BNDES/ Privatização - Moedas. 
- Os investimentos externos em moeda.

Apresentada de modo geral a entrada dos investimentos estrangeiros no Brasil é imperioso individualizar os investimentos externos em moeda.

A próxima tabela apresentada ${ }^{20}$ relaciona os investimentos diretos, em portifólio, os investimentos em fundo de renda fixa ${ }^{21}$ e nos demais fundos (como os fundos de renda variável e os fundos Hedge).

(em US\$ milhões)

\begin{tabular}{|c|c|c|c|c|c|c|c|c|c|c|c|c|c|c|c|}
\hline \multirow[t]{2}{*}{ Periodo } & \multicolumn{3}{|l|}{ Portifólio } & \multicolumn{3}{|l|}{ Direto } & \multicolumn{3}{|c|}{ Fundos renda fixa } & \multicolumn{3}{|c|}{ Demais fundos } & \multicolumn{3}{|l|}{ Total } \\
\hline & Ingressos $] \mathrm{F}$ & Relorno & Liquido & \begin{tabular}{|l|} 
Ingressos \\
\end{tabular} & Retorno & Liquido & \begin{tabular}{|l|} 
Ingressos \\
\end{tabular} & Retomo & Liquido & Ingressos & Retorno & Liquido & Ingresso & Retomo & Líquido \\
\hline 1992 & 3.864 & 2.160 & 1.704 & 1.324 & 170 & 1.154 & 0 & 0 & 0 & 0 & o & 0 & 5.188 & 2.330 & 2.858 \\
\hline 1990 & 14,971 & 8.380 & 6.591 & 877 & 480 & 397 & 80 & 0 & 80 & 0 & 0 & 이 & 15.928 & 8.860 & 7.068 \\
\hline 1994 & 21.600 & 16.521 & 5.079 & 2.241 & 329 & 1.912 & 1.434 & 86 & 1.348 & 1.939 & 956 & 983 & 27.214 & 17.892 & 9.322 \\
\hline 1995 & 22.559 & 17.806 & 4.753 & 3.285 & 315 & 2.970 & 211 & 1.196 & .985 & 1.955 & 1.451 & 504 & 28.010 & 20.768 & 7.242 \\
\hline 1996 -jan & 2.146 & 1.062 & 1084 & 466 & 11 & 455 & 2 & 1 & 1 & 610 & 282 & 328 & 3.224 & 1.356 & 1.868 \\
\hline 1996 fev & 2.012 & 1.405 & 607 & 273 & 38 & 235 & 2 & 0 & 4 & 166 & 96 & 70 & 2.453 & 1.539 & 916 \\
\hline 1996 -mar & 1.784 & 1.827 & -43 & 482 & 3 & 479 & 4 & 0 & 2 & 0 & 21 & -21 & 2.270 & 1.851 & 417 \\
\hline 1996 -abr & 1.729 & 1.155 & 574 & 510 & 32 & 478 & 2 & 0 & 3 & 1 & 3 & -2 & 2.242 & 1.190 & 1.053 \\
\hline $1996-\mathrm{mai}$ & 2.345 & 1.622 & 723 & 1.641 & 18 & 1.623 & 3 & 0 & 0 & 2 & 75 & -73 & 3.991 & 1.715 & 2.273 \\
\hline 1996 -jun & 1.502 & 1.720 & -218 & 1.105 & 2 & 1.103 & 0 & 0 & 0 & 0 & 2 & -2 & 2.607 & 1.724 & 883 \\
\hline 1996 -jul & 2.131 & 2.199 & -68 & 597 & 12 & 585 & 0 & 2 & -2 & 11 & 0 & 11 & 2.739 & 2.213 & 526 \\
\hline 1996 -ago & 1.961 & 1.234 & 727 & 434 & 5 & 429 & 0 & 1 & -1 & 1 & 40 & -39 & 2.396 & 1.280 & 1.116 \\
\hline 1996 -set & 1.731 & 1.100 & 631 & 354 & 6 & 348 & 0 & 1 & .1 & 54 & 52 & 2 & 2.139 & 1.159 & 980 \\
\hline 1996 out & 2.180 & 1.479 & 701 & 888 & 64 & 824 & -1 & 2 & .1 & 18 & 3 & 15 & 3.085 & 1.548 & 1.539 \\
\hline 1996 -nov & 2.365 & 1.647 & 718 & 1.014 & 115 & 899 & 0 & 1 & -1 & 5 & 110 & -105 & 3.384 & 1.873 & 1.511 \\
\hline 1996 -dez & 2.798 & 2.116 & 682 & 1.816 & 79 & 1.737 & 0 & 0 & 0 & 8 & 26 & -18 & 4.622 & 2.221 & 2.401 \\
\hline $\mid 1996-$ total & 24.684 & 18.566 & 6.118 & 9.580 & 385 & 9.195 & 12 & 8 & 4 & 876 & 710 & 166 & 35.152 & 19.669 & 15.483 \\
\hline 1997 -jan & 3.208 & 1.806 & 1.402 & 831 & 31 & 800 & 0 & 129 & -129 & 15 & 98 & 83 & 4.054 & 2.064 & 1.990 \\
\hline $1997 \cdot \mathrm{fev}$ & 2.713 & 1.514 & 1.199 & 304 & 32 & 272 & 0 & 0 & 0 & 1 & 2 & -1 & 3.018 & 1.548 & 1.470 \\
\hline$|1997-\operatorname{mat}|$ & 1.994 & 1.320 & 674 & 1.617 & 0 & 1.617 & 0 & 29 & -29 & 0 & 11 & -11 & 3.611 & 1.360 & 2.251 \\
\hline $1997-a b r$ & 2.328 & 1.805 & 523 & 1.496 & 30 & 1.466 & 0 & 210 & -210 & 35 & 63 & -28 & 3.859 & 2.108 & 1.751 \\
\hline 1997 -mai & 3.579 & 1.707 & 1.872 & 1.747 & 2 & 1.745 & 1 & 39 & -38 & 84 & 26 & 58 & 5.411 & 1.774 & 3.ळ7 \\
\hline 1997 -jun & 4.241 & 3.271 & 970 & 994 & 11 & 983 & 58 & 67 & -9 & 241 & 25 & 216 & 5.534 & 3.374 & 2.160 \\
\hline 1997 -jul & 4.143 & 3.393 & 750 & 1.400 & 19 & 1.381 & 7 & 112 & -105 & 258 & 59 & 199 & 5.808 & 3.583 & 2.225 \\
\hline 1997 -ago & 3.658 & 2.947 & 711 & 1.577 & 186 & 1.391 & 2 & 1 & 1 & 241 & 67 & 174 & 5.478 & 3.201 & 2.277 \\
\hline 1997 -set & 2.716 & 2.437 & 279 & 1.485 & 58 & 1.427 & 0 & 67 & -67 & 6 & 106 & -43 & 4.264 & 2.668 & 1.506 \\
\hline 1997 -out & 3.183 & 3.739 & -556 & 3.164 & 770 & 2.394 & 0 & 736 & .736 & 64 & 162 & -98 & 6.411 & 5.407 & 1.004 \\
\hline 1997 -nov & 2.711 & 3.869 & -1.558 & 1.553 & 330 & 1.223 & 3 & 386 & -383 & 68 & 18 & 50 & 4.335 & 4.603 & -668 \\
\hline 1997 -dez & 2.716 & 2.967 & .251 & $1 . \oplus 6$ & 65 & 1.631 & 327 & 50 & 277 & 197 & 60 & 137 & 4.936 & 3.142 & 1.794 \\
\hline $\mid 1997$-total & 37.190 & 30.775 & 6.015 & 17.864 & 1.534 & 16.330 & 398 & 1.826 & -1.428 & 1.267 & 67 & 570 & 56.719 & 34.832 & 21.487 \\
\hline
\end{tabular}

- Captação de Recursos Externos.

Observados os investimentos externos em moeda, pode-se apresentar um resumo de como ocorreu a captação dos recursos externos nos últimos quatro anos. Sendo que a discriminação das modalidades dos recursos externos será feita no item relacionado às modalidades de investimentos.

20. Dados colhidos no Banco Central

21. Sobre o caráter pouco volátil dos fundos de renda fixa tem-se que: "o segredo dos fundos de renda fixa é a idéia do condominio, ou seja, embora os aplicadores tenham o mesmo direito de resgatar suas cotas em curto prazo, nem todos o fazem ao mesmo tempo, isto é, sempre fica uma grande soma disponivel, que pode ser aplicada em titulos mais rentáveis" Fortuna, Eduardo. Mercado financeiro: produtos e serviços, São Paulo, Qualitymark Editora, 10ª ed., 1997. p. 230 
(em US\$ milhões)

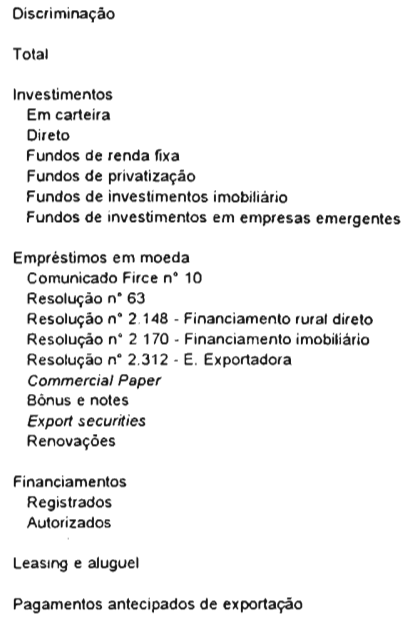

Pagamentos antecipados de exportaçáo

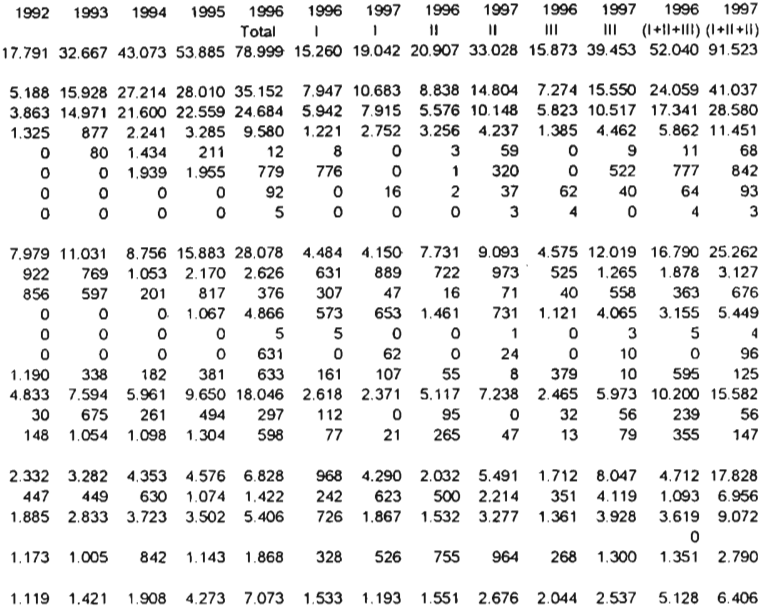

Para completar uma análise geral faz-se necessário quantificar os investimentos e os reinvestimentos estrangeiros relacionados por país, ${ }^{22}$ a fim de demonstrar os principais países investidores.

\section{(em US\$ milhões)}

\begin{tabular}{|c|c|c|c|c|c|c|c|c|c|}
\hline País & ano & Invest. & Reinv. & Total & Pais & ano & Invest. & Reinv. & Total \\
\hline África do Sul & 1992 & 0 & 0 & 0 & Alemanha & 1992 & 95.491 & 20.567 & 116.058 \\
\hline & 1993 & 0 & 0 & 0 & & 1993 & 108.187 & -766 & 107.421 \\
\hline & 1994 & 0 & 0 & 0 & & 1994 & 323.645 & 17.014 & 340.659 \\
\hline & 1995 & 0 & 0 & 0 & & 1995 & -9.687 & 0 & -9.687 \\
\hline Andorra & 1992 & 0 & 0 & 0 & Angola & 1992 & 0 & 0 & 0 \\
\hline & 1993 & 0 & 0 & 0 & & 1993 & 0 & 0 & 0 \\
\hline & 1994 & 0 & 0 & 0 & & 1994 & 0 & 0 & 0 \\
\hline & 1995 & 0 & 0 & 0 & & 1995 & 0 & 0 & 0 \\
\hline
\end{tabular}

22. Dados colhidos no Banco Central. 


\begin{tabular}{|c|c|c|c|c|c|c|c|c|c|}
\hline Antilhas Hol. & 1992 & 9. 166 & 10 & 9.176 & Arábia Saud. & 1992 & 0 & 0 & 0 \\
\hline & 1993 & 134.958 & -7.375 & 127.583 & & 1993 & 0 & 0 & 0 \\
\hline & 1994 & 152.413 & 25.068 & 177.481 & & 1994 & 0 & 0 & 0 \\
\hline \multirow[t]{3}{*}{ Argentina } & 1992 & 12.904 & 2 & 12.906 & Austrália & 1992 & 6.882 & 2.681 & 9.563 \\
\hline & 1993 & 12.229 & 273 & 12.502 & & 1993 & 176 & 0 & 176 \\
\hline & 1994 & 70.720 & 0 & 70.720 & & 1994 & 15.103 & 0 & 15.103 \\
\hline \multirow{3}{*}{ Austria } & 1993 & 8.660 & -150 & 8.510 & & 1993 & 653.115 & 3.373 & 656.488 \\
\hline & 1994 & 12.085 & 0 & 12.085 & & 1994 & 1.086 .534 & 13.136 & 1.099 .670 \\
\hline & 1995 & 0 & 0 & 0 & & 1995 & -857.113 & 0 & -857.113 \\
\hline \multirow[t]{2}{*}{ Bahrain } & 1992 & 0 & 0 & 0 & Barbados & 1992 & 0 & 0 & 0 \\
\hline & 1993 & 0 & 0 & 0 & & 1993 & 0 & 0 & 0 \\
\hline \multirow{2}{*}{ Bélgica } & 1994 & -35.489 & 12.551 & -22.938 & & 1994 & 44.988 & 0 & 44.988 \\
\hline & 1995 & 1.185 & 0 & 1.185 & & 1995 & 321.880 & 0 & 321.880 \\
\hline \multirow[t]{4}{*}{ Bolivia } & 1992 & 0 & 0 & 0 & Canadí & 1992 & 81.309 & -14 & 81.295 \\
\hline & 1993 & 0 & 0 & 0 & & 1993 & -34.325 & 11.752 & -22.573 \\
\hline & 1994 & 0 & 0 & 0 & & 1994 & 34.057 & 3.147 & 37.204 \\
\hline & 1995 & 0 & 0 & 0 & & 1995 & 4.072 & 0 & 4.072 \\
\hline \multirow[t]{4}{*}{ Cayman } & 1992 & 154.433 & -6.044 & 148.389 & Chile & 1992 & 10.089 & 0 & 10.089 \\
\hline & 1993 & 1.855 .964 & 7.144 & 1.863 .108 & & 1993 & -2.365 & 0 & -2.365 \\
\hline & 1994 & 398.214 & 1.593 & 399.807 & & 1994 & 14.381 & 0 & 14.381 \\
\hline & 1995 & -2.415 .987 & 0 & -2.415 .987 & & 1995 & -187 & 0 & -187 \\
\hline China Cont. & 1992 & 134 & 0 & 134 & Chipre & 1992 & 0 & 0 & 0 \\
\hline
\end{tabular}




\begin{tabular}{|c|c|c|c|c|c|c|c|c|c|}
\hline & 1993 & 0 & 0 & 0 & & 1993 & 0 & 0 & 0 \\
\hline & 1994 & 0 & 0 & 0 & & 1994 & 800 & 0 & 800 \\
\hline & 1995 & 0 & 0 & 0 & & 1995 & 0 & 0 & 0 \\
\hline \multirow[t]{4}{*}{ Coréia do Nor. } & 1992 & 0 & 0 & 0 & Coréia do Sul & 1992 & 66 & 0 & 66 \\
\hline & 1993 & 0 & 0 & 0 & & 1993 & 76 & 0 & 76 \\
\hline & 1994 & -37 & 0 & -37 & & 1994 & 2.018 & 6 & 2.024 \\
\hline & 1995 & 0 & 0 & 0 & & 1995 & 0 & 0 & 0 \\
\hline \multirow[t]{4}{*}{ Costa Marfim } & 1992 & 0 & 0 & 0 & Costa Rica & 1992 & 0 & 5 & 5 \\
\hline & 1993 & 0 & 0 & 0 & & 1993 & 0 & 11 & 11 \\
\hline & 1994 & 0 & 0 & 0 & & 1994 & 0 & 0 & 0 \\
\hline & 1995 & 0 & 0 & 0 & & 1995 & 0 & 0 & 0 \\
\hline \multirow[t]{4}{*}{ Coveite } & 1992 & 76.106 & 0 & 76.106 & Dinamarca & 1992 & 8.692 & 896 & 9.588 \\
\hline & 1993 & 0 & 0 & 0 & & 1993 & -444 & -1.826 & -2.270 \\
\hline & 1994 & 0 & 0 & 0 & & 1994 & 6.752 & 129 & 6.881 \\
\hline & 1995 & 0 & 0 & 0 & & 1995 & 4.694 & 0 & 4.694 \\
\hline \multirow[t]{4}{*}{ Egito } & 1992 & 0 & 0 & 0 & Equador & 1992 & 0 & 0 & 0 \\
\hline & 1993 & 0 & 0 & 0 & & 1993 & 0 & 0 & 0 \\
\hline & 1994 & 0 & 0 & 0 & & 1994 & 0 & 0 & 0 \\
\hline & 1995 & 0 & 0 & 0 & & 1995 & 0 & 0 & 0 \\
\hline \multirow[t]{4}{*}{ Espanha } & 1992 & 30.379 & 883 & 31.262 & EUA & 1992 & 1.353 .408 & -26.921 & 1.326 .487 \\
\hline & 1993 & 39.160 & 484 & 39.644 & & 1993 & 3.106 .592 & -113.946 & 2.992 .646 \\
\hline & 1994 & 6.067 & 0 & 6.067 & & 1994 & 3.642 .193 & -17.161 & 3.625 .032 \\
\hline & 1995 & 30 & 0 & 30 & & 1995 & -350.192 & 0 & -350.192 \\
\hline \multirow[t]{4}{*}{ Estônia } & 1992 & 0 & 0 & 0 & Finlândia & 1992 & -188 & 68 & -120 \\
\hline & 1993 & 0 & 0 & 0 & & 1993 & 2.721 & 0 & 2.721 \\
\hline & 1994 & 0 & 0 & 0 & & 1994 & 244 & 0 & 244 \\
\hline & 1995 & 0 & 0 & 0 & & 1995 & 0 & 0 & 0 \\
\hline \multirow[t]{4}{*}{ Form.-Taiwan } & 1992 & 0 & 0 & 0 & França & 1992 & 30.776 & -31.597 & -821 \\
\hline & 1993 & 0 & 0 & 0 & & 1993 & 112.110 & 3.965 & 116.075 \\
\hline & 1994 & 204 & 0 & 204 & & 1994 & 255.514 & 23.238 & 278.752 \\
\hline & 1995 & 0 & 0 & 0 & & 1995 & -15.871 & 0 & -15.871 \\
\hline \multirow[t]{2}{*}{ Gibraltar } & 1992 & 15 & 20 & 35 & Grécia & 1992 & 0 & 0 & 0 \\
\hline & $\{993$ & 52 & 0 & 52 & & 1993 & 0 & 0 & 0 \\
\hline
\end{tabular}




\begin{tabular}{|c|c|c|c|c|c|c|c|c|c|}
\hline & 1994 & 638 & 0 & 638 & & 1994 & 0 & 0 & 0 \\
\hline & 1995 & 0 & 0 & 0 & & 1995 & 0 & 0 & 0 \\
\hline \multirow[t]{4}{*}{ Guia. Frances. } & 1992 & 12 & 0 & 121 & Holanda & 1992 & 188.016 & 93.809 & 281.825 \\
\hline & 1993 & 0 & 0 & 0 & & 1993 & 269.229 & 9.564 & 278.793 \\
\hline & 1994 & 0 & 0 & 0 & & 1994 & 53.701 & 2.322 & $56.02 j$ \\
\hline & 1995 & 0 & 0 & 0 & & 1995 & .10 .143 & 0 & -10.143 \\
\hline \multirow[t]{4}{*}{ Hong-Kong } & 1992 & 1.280 & 0 & 1.280 & Hungria & 1992 & 0 & 0 & $\underline{0}$ \\
\hline & 1993 & -2.901 & 0 & -2.901 & & 1993 & 0 & 0 & 0 \\
\hline & 1994 & 178 & 0 & 178 & & 1994 & 0 & 0 & 0 \\
\hline & 1995 & 0 & 0 & 0 & & 1995 & 0 & 0 & 0 \\
\hline \multirow[t]{4}{*}{ india } & 1992 & 75 & 0 & 75 & Irã & 1992 & 0 & 0 & 0 \\
\hline & 1993 & 9 & 0 & 9 & & 1993 & 0 & 0 & 0 \\
\hline & 1994 & 0 & 0 & 0 & & 1994 & 0 & 0 & 0 \\
\hline & 1995 & 0 & 0 & 0 & & 1995 & 0 & 0 & 0 \\
\hline \multirow[t]{4}{*}{ Iraque } & 1992 & 0 & 0 & 0 & Irlanda do Sul & 1992 & 942 & 0 & 942 \\
\hline & 1993 & 0 & 0 & 0 & & 1993 & 2.665 & 0 & 2.665 \\
\hline & 1994 & 0 & 0 & 0 & & 1994 & 85.382 & 0 & 85.382 \\
\hline & 1995 & 0 & 0 & 0 & & 1995 & -28.148 & 0 & -28.148 \\
\hline \multirow[t]{4}{*}{ Isracl } & 1992 & 558 & 0 & 558 & Itiliat & 1992 & -79.643 & -54.984 & -134.627 \\
\hline & 1993 & -1.410 & 0 & $-1 .+10$ & & 1993 & 511.206 & 1.450 & 512.656 \\
\hline & 1994 & 19 & 0 & 19 & & 1994 & 14.592 & 314 & 14.906 \\
\hline & 1995 & 0 & 0 & 0 & & 1995 & 50 & 0 & 50 \\
\hline \multirow[t]{4}{*}{ lugoslávia } & 1992 & -26 & 0 & -26. & Jap:io & 1992 & 74.860 & 285 & 75.145 \\
\hline & 1993 & 0 & 0 & 0 & & 1993 & 37.131 & -10.419 & 26.712 \\
\hline & 1994 & 0 & 0 & 0 & & 1994 & 76.324 & -812 & 75.512 \\
\hline & 1995 & 0 & 0 & 0 & & 1995 & 18.738 & 144 & 18.882 \\
\hline \multirow[t]{4}{*}{ Jordânia } & 1992 & 0 & 0 & 0 & Leeward & 1992 & 954 & 0 & 954 \\
\hline & 1993 & 0 & 0 & 0 & & 1993 & 19.736 & 0 & 19.736 \\
\hline & 1994 & 0 & 0 & 0 & & 1994 & -8.552 & 0 & -8.552 \\
\hline & 1995 & 0 & 0 & 0 & & 1995 & -42 & 0 & -42 \\
\hline \multirow[t]{3}{*}{ Libano } & 1992 & 333 & 0 & 333 & Libéria & 1992 & 569 & 0 & 569 \\
\hline & 1993 & 62 & 0 & 62 & & 1993 & 609 & 0 & 609 \\
\hline & 1904 & 0 & 0 & 0 & & 1994 & 492 & 0 & 492 \\
\hline
\end{tabular}




\begin{tabular}{|c|c|c|c|c|c|c|c|c|c|}
\hline & 1995 & 0 & 0 & 0 & & 1995 & 0 & 0 & 0 \\
\hline \multirow[t]{4}{*}{ Liechtenstein } & 1992 & 52.570 & 31 & 52.601 & Luxemburgo & 1992 & -7.357 & -4.100 & -11.457 \\
\hline & 1993 & 2.607 & 5 & 2.612 & & 1993 & 131.253 & -934 & 130.319 \\
\hline & 1994 & 4.774 & 2.547 & 7.321 & & 1994 & 96.045 & 235 & 96.280 \\
\hline & 1995 & 3.987 & 0 & 3.987 & & 1995 & 25.005 & 0 & 25.005 \\
\hline \multirow[t]{4}{*}{ Malásia } & 1992 & 36 & 0 & 36 & Malgaxe & 1992 & 0 & 0 & 0 \\
\hline & 1993 & 0 & 0 & 0 & & 1993 & 0 & 0 & 0 \\
\hline & 1994 & 0 & 0 & 0 & & 1994 & 0 & 0 & 0 \\
\hline & 1995 & 0 & 0 & 0 & & 1995 & 0 & 0 & 0 \\
\hline \multirow[t]{4}{*}{ Malta } & 1992 & 214 & 0 & 214 & Marrocos & 1992 & 0 & 0 & 0 \\
\hline & 1993 & 0 & 0 & 0 & & 1993 & 0 & 0 & 0 \\
\hline & 1994 & 0 & 0 & 0 & & 1994 & 0 & 0 & 0 \\
\hline & 1995 & 0 & 0 & 0 & & 1995 & 0 & 0 & 0 \\
\hline \multirow[t]{4}{*}{ México } & 1992 & -714 & 0 & -714 & Mônaco & 1992 & 0 & 0 & 0 \\
\hline & 1993 & 47 & -1 & 46 & & 1993 & 0 & 0 & 0 \\
\hline & 1994 & 259 & 0 & 259 & & 1994 & 0 & 0 & 0 \\
\hline & 1995 & -50 & 0 & -50 & & 1995 & 0 & 0 & 0 \\
\hline \multirow[t]{4}{*}{ Nigéria } & 1992 & 0 & 0 & 0 & Noruega & 1992 & 0 & 0 & 0 \\
\hline & 1993 & 0 & 0 & 0 & & 1993 & -23.821 & 0 & -23.821 \\
\hline & 1994 & 0 & 0 & 0 & & 1994 & 382 & 148 & 530 \\
\hline & 1995 & 0 & 0 & 0 & & 1995 & 0 & 0 & 0 \\
\hline \multirow[t]{4}{*}{ Nova Zelândia } & 1992 & 647 & 0 & 647 & Panamı́ & 1992 & 61.259 & 44.438 & 105.697 \\
\hline & 1993 & 629 & 0 & 629 & & 1993 & 33.571 & -503 & 33.068 \\
\hline & 1994 & 410 & 0 & 410 & & 1994 & 7.025 & -18.854 & -11.829 \\
\hline & 1995 & 0 & 0 & 0 & & 1995 & 5 & 265 & 270 \\
\hline \multirow[t]{4}{*}{ Pápua } & 1992 & 0 & 0 & 0 & Paraguai & 1992 & 50.537 & 0 & 50.537 \\
\hline & 1993 & 0 & 0 & 0 & & 1993 & 1.632 & 0 & 1.632 \\
\hline & 1994 & 0 & 0 & 0 & & 1994 & -19.303 & 0 & -19.303 \\
\hline & 1995 & 0 & 0 & 0 & & 1995 & -18.716 & 0 & -18.716 \\
\hline \multirow[t]{4}{*}{ Peru } & 1992 & 0 & 0 & 0 & Polônia & 1992 & 0 & 0 & 0 \\
\hline & 1993 & 0 & 0 & 0 & & 1993 & 0 & 0 & 0 \\
\hline & 1994 & 0 & 0 & 0 & & 1994 & 0 & 0 & 0 \\
\hline & 1995 & 0 & 0 & 0 & & 1995 & 0 & 0 & 0 \\
\hline
\end{tabular}




\begin{tabular}{|c|c|c|c|c|c|c|c|c|c|}
\hline \multirow{4}{*}{\begin{tabular}{|l} 
Porto Rico \\
\end{tabular}} & 1992 & 0 & 0 & 0 & Portugal & 1992 & 146 & 1.217 & 1.363 \\
\hline & 1993 & 0 & 0 & 0 & & 1993 & 59.462 & 1.452 & 60.914 \\
\hline & 1994 & 221.449 & 0 & 221.449 & & 1994 & 194.737 & 1.420 & 196.157 \\
\hline & 1995 & -97.568 & 0 & -97.568 & & 1995 & 0 & 0 & 0 \\
\hline \multirow[t]{4}{*}{ Reino Unido } & 1992 & 379.398 & -5.135 & 374.263 & Rep. Domin. & 1992 & 0 & 0 & 0 \\
\hline & 1993 & 942.248 & -18.532 & 923.716 & & 1993 & 0 & 0 & 0 \\
\hline & 1994 & 1.711 .367 & 3.569 & 1.714 .936 & & 1994 & 0 & 0 & 0 \\
\hline & 1995 & -217.018 & 0 & -217.018 & & 1995 & 0 & 0 & 0 \\
\hline \multirow[t]{4}{*}{ Rússia } & 1992 & 0 & 0 & 0 & Suécia & 1992 & -52.411 & .8 .437 & -60.848 \\
\hline & 1993 & 0 & 0 & 0 & & 1993 & -157 & 16.293 & 16.136 \\
\hline & 1994 & 0 & 0 & 0 & & 1994 & -7.725 & -1.147 & -8.872 \\
\hline & 1995 & 0 & 0 & 0 & & 1995 & -5.721 & 0 & -5.721 \\
\hline \multirow[t]{4}{*}{ Suiça } & 1992 & 54.945 & -23.429 & 31.516 & Rep. Tcheca & 1992 & 0 & 0 & 0 \\
\hline & 1993 & 51.495 & 21.314 & 72.809 & & 1993 & 0 & 0 & 0 \\
\hline & 1994 & -13.533 & -28.575 & -42.108 & & 1994 & 0 & 0 & 0 \\
\hline & 1995 & -18.518 & 2.958 & -15.560 & & 1995 & 0 & 0 & 0 \\
\hline \multirow[t]{4}{*}{ Uruguai } & 1992 & 31.317 & 683 & 32.000 & Venezuela & 1992 & 9.712 & 0 & 9.712 \\
\hline & 1993 & 124.419 & 378 & 124.797 & & 1993 & 4.885 & 0 & 4.885 \\
\hline & 1994 & 44.355 & 46 & 44.401 & & 1994 & -5.399 & 0 & -5.399 \\
\hline & 1995 & 15.883 & 0 & 15.883 & & 1995 & 0 & 0 & 0 \\
\hline \multirow[t]{4}{*}{ Virg. Ilha-RU } & 1992 & 1.035 & 0 & 1.035 & Virg. Ilha-EUA & 1992 & 9.242 & 803 & 10.045 \\
\hline & 1993 & -324 & 0 & $-\hat{3} 24$ & & 1993 & 8.333 & 0 & 8.333 \\
\hline & 1994 & -150 & 0 & -150 & - & 1994 & 3.890 & 0 & 3.890 \\
\hline & 1995 & 0 & 0 & 0 & & 1995 & 628 & 0 & 628 \\
\hline \multirow[t]{4}{*}{ Org. Internac. } & 1992 & & & 0 & & & & & \\
\hline & 1993 & & & 0 & & & & & \\
\hline & 1994 & & & 0 & & & & & \\
\hline & 1995 & & & 0 & & & & & \\
\hline \multirow[t]{4}{*}{ Total Geral } & 1992 & 2.829 .850 & 56.598 & 2.886 .449 & & & & & \\
\hline & 1993 & 8.301 .836 & -77.025 & 8.224 .810 & & & & & \\
\hline & 1994 & 8.577 .217 & 40.273 & $8.617,490$ & & & & & \\
\hline & 1995 & -3.842 .188 & 3.367 & -3.838 .820 & & & & & \\
\hline
\end{tabular}


c. Modalidades de Investimentos.

$\mathrm{O}$ intuito do presente item é relacionar as principais formas de entrada dos investimentos estrangeiros.

- Investimentos diretos.

O FMI, ${ }^{23}$ a $\mathrm{OCDE}^{24}$ e o $\mathrm{MIGA}^{25}$ classificam como investimentos diretos àqueles que têm a finalidade de obter participação duradoura em uma empresa. O Banco Central considera como tais investimentos àqueles que tenham por fim adquirir no mínimo $10 \%$ do capital votante ou $20 \%$ do capital total. ${ }^{26}$

Os investimentos diretos, segundo o Banco Central, ${ }^{27}$ poderão ser efetivados nas seguintes formas: moeda (estrangeira ou nacional), ${ }^{28}$ mercadorias (máquinas e equipamentos), bens intangíveis (marcas, patentes ou créditos relativos ao pagamento de tecnologia) e conversão de dívida, como as "moedas de privatização"

Outra classificação adotada pelo Banco Central divide os investimentos diretos segundo três naturezas básicas. A primeira tange aos investimentos em imóveis, a segunda em subsidiárias e filiais, onde distinguimos as empresas transnacionais e as empresas globais e a terceira em participações em empresas no país, onde incluem-se os investimentos duradouros feitos no PND.

23. Fundo Monetário Internacional.

24. Organização Econômica de Cooperação e Desenvolvimento.

25. Agência Multilateral de Garantia de Investimento

26. Banco Central. Boletim, 1997

27. Banco Central. Resenha Econômica, 1997.

28. Cabe lembrar que o critério que diferencia os investimentos nacionais dos investimentos estrangeiros é o pais de origem. 
- Investimentos em Carteira ou Portifólio.

Os investimentos em portifólio são os investimentos que não têm por fim estabelecer vínculo duradouro ${ }^{29}$ entre o investido e o investidor, estando sujeitos a bruscas flutuações.

Utilizando as Resoluções do Banco Central e as Instruções da CVM pode-se dividir os investimentos em carteira ou portifólio sob a seguinte óptica:

- Regulamentos anexos à Resolução n. 1.289 de 20.03.87.

$\mathrm{O}$ anexo I à Resolução n. 1.289 de 20.03.87, refere-se aos investimentos estrangeiros efetuados através de sociedades anônimas de capital autorizado, que estão sujeitas à autorização do Banco Central e à aplicação de no mínimo $50 \%$ em ações, sendo que os recursos remanescentes poderão ser aplicados de acordo com o art. $2^{\circ}$ I da Resolução n. 2.344 de $19.12 .96,{ }^{30}$ que modificou o art. 44 do Regulamento Anexo I da Resolução n. 1.289 de 20.03.87.

$\mathrm{O}$ anexo II da Resolução regulamenta os Fundos de Investimento de Capital Estrangeiro que são definidos pelo Banco Central como os constituídos sob forma de condomínio aberto, congregando recursos externos de pessoas físicas ou jurídicas residentes, domiciliadas ou com sede no exterior, de fundos ou outras entidades de investimento coletivo estrangeiro, destinados à aplicação em carteira diversificada de títulos e valores mobiliários.

A modalidade de aplicação desses fundos é de no mínimo $70 \%$ em ações de emissões de companhias abertas adquiridas em bolsa de valores, mercado de balcão ou por subscrição, sendo que são facultados aos recursos remanescentes

29. Mesmo na classificação do Banco Central, com relação aos investimentos diretos, subentendese uma participação duradoura.

30. Os recursos remanescentes poderão ser aplicados isolados ou cumulativamente em ações de companhias registradas em bolsa de valores adquiridas em bolsa ou por subscrição; debêntures conversíveis em ações de distribuição pública, desde que emitidas a partir 01.11.96 e com prazo de vencimento igual ou superior a três anos; ações sem direito a voto de emissão de instituições financeiras com sede no pais, com ações negociadas em bolsa de valores e outras modalidades de investimentos previamente autorizadas, em conjunto, pelo Banco Central e pela CVM. 
serem aplicados em concordância com o inciso II do art. $2^{\circ}$ da Resolução n. $2.344,{ }^{31}$ que alterou o art. 41 do Regulamento Anexo II da Resolução n. 1.289.

Os fundos dessas modalidades criados a partir de 1987, possuem limites de aplicação e custos de administração mais elevados do que os investimentos realizados sob a égide do anexo I, desta forma são freqüentemente utilizados pelo pequeno investidor externo que não dispõe de administração própria para gerenciar os seus recursos. ${ }^{32}$

$\mathrm{O}$ anexo III regulamenta a carteira de títulos e valores mobiliários para investidores institucionais estrangeiros, diferindo do anexo anterior somente ${ }^{33}$ pelo fato de não apresentar limite para a diversificação de risco de aplicação. Este anexo abrange os fundos de pensão, carteiras de instituições financeiras, fundos de investimentos e seguradoras.

No anexo IV, incluído na Resolução n. 1.289 por força da Resolução n. 1.832, encontra-se a regulamentação para a aplicação direta dos investidores institucionais estrangeiros em bolsa de valores. Pelo fato desses fundos possuírem alta taxa de manobra e baixo custo de administração têm concentrado os grandes investidores externos.

As modalidades de aplicação deste inciso destinam-se a valores mobiliários de rendimentos não-predeterminados, ${ }^{34}$ sendo que os recursos nãoaplicados nesses valores mobiliários poderão ser aplicados isolados ou cumulativamente em debêntures conversíveis em ações de distribuição pública, desde que emitidas a partir de 01.11.96, com prazo de vencimento igual ou superior a 3 (três) anos; ações sem direito a voto, negociadas em bolsa de valores, de emissão

31. Debêntures conversiveis em ações de distribuição pública, desde que emitidas a partir de 01.11.96, com prazo de vencimento igual ou superior a três anos; ações sem direito a voto de emissão de instituições financeiras com sede no pais, com ações negociadas em bolsas de valores; outros valores mobiliários de emissão de companhias abertas, observado o disposto no art. $3^{\circ}$ da Resolução $\mathrm{n}$. 2.034 de 17.12.93; outras modalidades de investimento expressamente autorizadas, em conjunto, pelo Banco Central e pela CVM.

32. Fortuna, Eduardo. Mercado financeiro: produtos e serviços, São Paulo, Qualitymark Editora, $10^{\mathrm{a}}$ ed., 1997.

33. Modalidade de aplicação é idêntica, inclusive no tocante aos recursos remanescentes.

34. A aplicação em valores mobiliários de renda fixa é vedada pelo art. $3^{\circ}$ da Resolução n. 2.034 de 17.12.93, com redação dada pela Resolução n. 2.344 , art. $3^{\circ}$. 
de instituições financeiras com sede no país ou outras modalidades de investimento expressamente autorizadas pelo Banco Central e pela CVM. ${ }^{35}$

Para que o capital estrangeiro possa entrar no país para os investimentos disciplinados neste anexo é necessário que um representante local do investidor (instituição financeira nacional) solicite o registro do investidor na CVM, que segue as normas do Capítulo I da Resolução n. 1.832 de 31.05.91. ${ }^{36}$

A Resolução n. 1.927 de 15.06.92 incluiu o anexo V na Resolução n. 1.289 que disciplina os investimentos de capitais estrangeiros no país através de Depositary Receipts.

Os Depositary Receipts são títulos emitidos por um banco estrangeiro (no caso das ADRs por um banco americano) lastreados por uma empresa de outro país.

Os DRs são definidos pelo Banco Central como sendo os certificados representativos de ações ou outros valores mobiliários que representem direitos a ações, emitidos no exterior por instituição depositária com lastro em valores mobiliários depositados em custódia específica no Brasil. ${ }^{37}$

Com a possibilidade do mercado de ações operar via DRs notou-se um aumento dos fluxos de investimentos via portifólio, no entanto, como já foi registrado, este tipo de investimento é muito suscetível a bruscas variações.

- Fundos de Renda Fixa para o Capital Estrangeiro.

Fundo disciplinado pela Resolução n. 2.034 de 17.12 .93 que tem a finalidade de captação de recursos externos para investimentos em títulos de emissão do Tesouro Nacional ou Banco Central, separada ou cumulativamente, e em ativos de renda fixa emitidas por empresas e instituições sediadas no país.

As modalidades de aplicação são de no mínimo de $35 \%$ em títulos de emissão do Banco Central ou Tesouro Nacional, separada ou cumulativamente;

35. Art. 27 do Regulamento. Anexo IV da Resolução n. 1.289, com redação dada pela Resolução n. 2.344 , art. $2^{\circ}$, IV.

36. O prazo para a análise do registro é de 30 (trinta) dias, sendo que poderá ser interrompido uma única vez em caso de solicitação de documentos. Decorrido o prazo sem que haja manifestação da CVM o registro do investidor considera-se aprovado.

37. Art. $1^{\circ}, 1$ da Resolução n. 1.927. 
máximo de $20 \%$ em títulos de renda fixa de emissão ou aceite de instituições financeiras e valores mobiliários de renda fixa.

Segundo os dados colhidos no Banco Central a expressividade desses fundos é baixa: o somatório dos investimentos nessa modalidade nos primeiros nove meses de 1997 foi de 68 milhões contra 41.037 milhões em investimentos em portifólio e 28.580 milhões em investimentos diretos. ${ }^{38}$

- Fundos de Privatização.

Os fundos de privatização foram autorizados pela Resolução n. 1.806 de 27.03.91 e regulamentados pela Instrução CVM n. 175 de 06.02.92 e tem por fim o investimento estrangeiro por moeda corrente ou moeda de privatização.

As moedas de privatização, ${ }^{39}$ por Resolução do Conselho Monetário Nacional, a partir de setembro de 1995 não sofrem mais o deságio de $25 \%$ sobre o valor de face e são de permanência compulsória no país por um prazo de seis anos contados da data da efetiva conversão. ${ }^{40}$

A expressividade desses fundos até outubro de 1997 foi 13\% da receita total do PND. ${ }^{41}$

- Fundos de Investimento Imobiliário.

São fundos constituídos sob a forma de condomínio fechado ${ }^{42}$ lastreados em empreendimentos imobiliários.

Nessa modalidade de investimentos o resgate não é admitido, assim quem desejar sair dos fundos deverá colocar as suas quotas em bolsa de valores ou em mercado de balcão.

38. Para maiores detalhamentos ver tabela sobre captação de recursos externos.

39. Debêntures de Sidebrás SIRB; Certificados de Privatizações CP; Obrigações do Fundo Nacional do Desenvolvimento OFND; Créditos Vencidos Renegociados (securitizados) DISEC; Títulos da Divida Agrária TDA; Títulos da Dívida Externa DIVEX; Letras Hipotecárias da Caixa Econômica Federal - CEF; Notas do Tesouro Nacional, série M - NTN-M.

40. Banco Central. Resenha Econômica, 1997.

41. BNDES: Privatizações/Moedas.

42. Apenas entra em funcionamento após adquiridas todas as quotas disponiveis. 
A regulamentação desse fundo é feita pela Lei n. 8.668/93 e pelas Instruções CVM n. 205 e 206 de 14.01.94, sendo que a Resolução n. 2.248 de 08.02.96 autorizou o ingresso do investimento estrangeiro nesses fundos, que nos primeiros nove meses de 1997 foram superiores em 36,7\% aos fundos de renda fixa.

- Fundos de investimentos em empresas emergentes FIEE.

Essa modalidade de fundos destina-se às empresas que apresentem um faturamento líquido anual inferior ao equivalente a 30 milhões de URVs, apurado no balanço de encerramento do exercício anterior à aquisição dos valores mobiliários de sua emissão. ${ }^{43}$

Da mesma forma que o fundo anterior é constituído em condomínio fechado, sendo que a autorização de ingressos de capitais estrangeiros de pessoas físicas ou jurídicas, residentes e domiciliadas no exterior, fundos e outras entidades de investimento coletivo estrangeiro está normatizada na Resolução n. 2.247 de 08.02.96.

A composição e diversificação da carteira deste fundo segue as normas do Capítulo VI da Instrução CVM n. 209 de 25.03.94.

- Outras formas de captação de Recursos Externos.

O intuito deste item é somente apresentar uma visão ampla e geral de outras formas de captação de Recursos Externos que não sejam em investimentos propriamente ditos.

Dentre essas outras formas de captação de Recursos Externos encontram-se os Bônus e os Eurobônus fixed e floating (empréstimos em moeda) que constituem uma forma de captação de recursos em valores elevados por empresas nacionais com penetração internacional. Essa modalidade de captação que se tem expandido pela questão da negociabilidade das posições ativas e passivas em diferentes moedas e prazos (operação de swap). ${ }^{44}$

43. Art. $1^{\circ}, \S 1^{\circ}$ da Instrução CVM n. 209 de 25.03.94.

44. De modo geral, a operação de swap caracteriza-se por ser uma operação de trocas de posições, como por exemplo o caso de companhias com dívidas em dólar corrigidas por taxas flutuantes utilizaria-se do swap para transformar a sua dívida em taxas fixas (Interest Rate Swap). 
Os Bônus e os Eurobônus permitem as operações $63^{45}$ e as operações 63-caipira ${ }^{46}$ (Financiamento Rural Direto) que caracterizam-se pela tomada de empréstimos do exterior por um banco no país e repasse casado em prazo e composição de taxas - para as empresas internas, abrangendo as agroindústrias e o financiamento de produtores rurais e suas cooperativas.

Uma outra forma de captação é a Securitização das Exportações autorizada pela Circular n. 1.979 do Banco Central de 26.06.91 que permitiu através da "Emissão de um título no mercado internacional com lastro em vendas futuras no exterior" que um exportador conseguisse obter financiamentos no exterior a custos menores.

Por fim, pode-se citar o comunicado Firce $^{47}$ n. 10 que normativiza os procedimentos necessários às empresas não-financeiras ${ }^{48}$ que desejam captar empréstimos em moeda estrangeira no exterior.

d. Importância dos Investimentos Estrangeiros. ${ }^{49}$

Os aportes de capitais estrangeiros estão diretamente ligados ao desenvolvimento de muitas economias, especialmente as dos países em desenvolvimento como é o caso do Brasil.

O desenvolvimento dessas economias é ocasionado pelo fato de que os

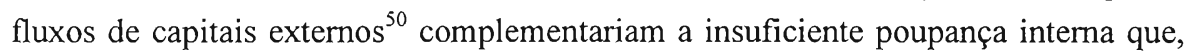
justamente pela sua escassez, proporcionariam maiores taxas de retorno ao investimento estrangeiro, atraindo-o portanto.

45. As operações 63 são as reguladas pela Resolução n. 63 do Banco Central e diferenciam-se, em linhas gerais, das operações realizadas sob a égide da Lei $n$. 4.131 pelo fato de que nesta última os recursos internacionais captados estão em nome de uma instituição jurídica não-financeira intermediada por uma instituição financeira.

46. Reguladas pela Resolução n. 2.148 do Banco Central.

47. Departamento de Fiscalização e Registro de Capitais Estrangeiros.

48. As empresas financeiras estão sujeitas à Resolução n. 63.

49. Entenda-se neste item por investimentos amplos, envolvendo investimentos em mercadorias, investimento societário tradicional, conversões de dívida, reinvestimentos e ingressos em bolsa ou mercado de capitais.

50. É necessário, a princípio, englobar os fluxos de capitais como um todo para extrair a importância dos investimentos estrangeiros. 
Esses fluxos de capitais externos proporcionariam a longo prazo um crescimento da economia e poupança internas, possibilitando a reversão da dívida externa sem o desaquecimento da economia interna. ${ }^{51}$

Pode-se perceber esta tendência de reversão pelo relacionamento dos coeficiente obtidos pela Divisão das Reservas Internas pela Dívida Externa e pela Divisão da Dívida Externa Total pelo PIB, como se observa no gráfico abaixo.

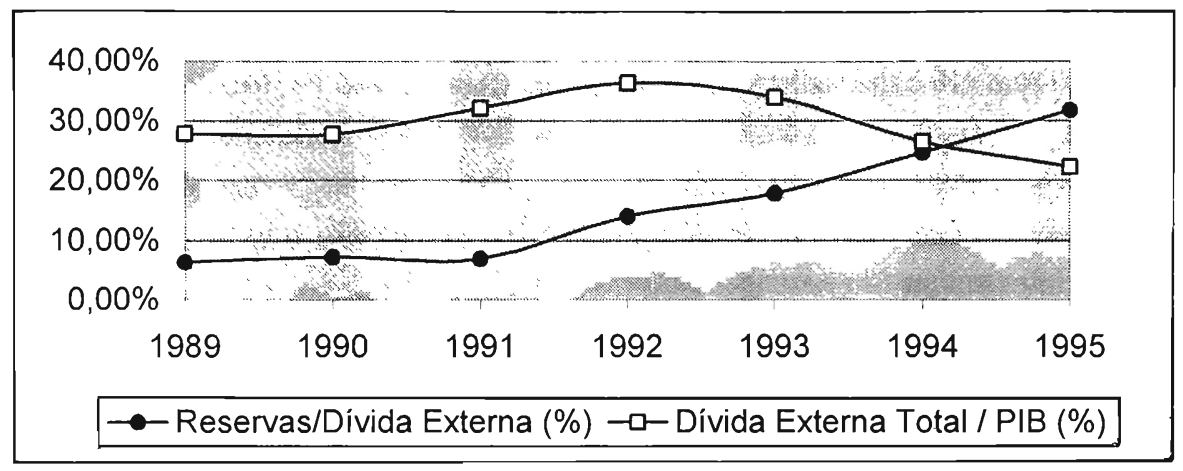

$\mathrm{Na}$ função registrada pelo coeficiente Reservas/Dívida Externa percebe-se que as reservas internas estão crescendo em relação à dívida externa total e na função dada pelo coeficiente da dívida externa total/PIB nota-se crescimento do PIB sobre a dívida externa total, verificando-se um crescimento econômico que a longo prazo poderá possibilitar o pagamento da dívida externa.

Dentre os fluxos de investimentos estrangeiros os investimentos diretos são considerados os mais atraentes a medida que estão menos sujeitos a mudanças bruscas ocasionadas pela política macroeconômica globalizada. Neste particular, o Brasil tem apresentado, a partir de 1994, um crescente aumento dos investimentos diretos sobre as outras modalidades de investimentos.

Os influxos de capitais estrangeiros via Mercado Internacional de títulos constituem, também, importante fonte de financiamento para o Brasil, proporcionado a "vantagem" da diluição dos riscos, à medida que dispersam a dívida externa por diferentes investidores e em diferentes praças, ao revés do ocorrido no

51. Pellegrini, Josué A., "Os fluxos Recentes de Capital para a América Latina", tese de Doutorado apresentada na Universidade de São Paulo, 1995. 
auge da captação bancária, ou seja: proporciona um endividamento de padrão superior. $^{52}$

Assim, de uma forma geral pode-se dizer que Brasil de hoje está dependente dos fluxos dos capitais estrangeiros para obter um nível satisfatório de crescimento econômico e ter atendida a demanda social do desemprego.

Essa dependência, no entanto, tem-se dado de forma satisfatória para o Brasil, na medida em que a dívida externa encontra-se dispersa por diferentes países e os investimentos internacionais diretos que proporcionam um desenvolvimento equilibrado da economia vêm crescendo.

Inclusive pode-se dizer que o Brasil não está sendo alvo de constantes especulações financeiras prejudiciais à estabilidade da economia, já que apesar dos investimentos em carteira serem elevados, os investimentos diretos vêm apresentando taxa de crescimento superior aos investimentos em carteira, fato que possibilita um crescimento adequado da economia, livrando-a cada vez mais das possíveis flutuações bruscas de liquidez. Em suma: "... mesmo os maiores críticos do investimento estrangeiro não negam a necessidade de capitais, e não deixam de almejar atraí-los. O que varia é a forma como serão aceitos mais facilmente." 53

e. O tratamento jurídico dos Investimentos Internacionais no Brasil.

A movimentação de capitais estrangeiros está relacionada com as condições que o país-hospedeiro oferece para o Capital estrangeiro, já que um investidor internacional preferirá o país de menor risco, se os retornos esperados forem iguais ou o de maior retorno se os riscos forem iguais. ${ }^{54}$

Dentre as condições oferecidas pelo país-receptor dos investimentos, ponderadas pelo investidor internacional, destacam-se três aspectos: os econômicos, os financeiros e os jurídicos. Os aspectos econômicos abrangem a existência de

52. Barros, Octavio de. Estudo da competitividade da Indústria brasileira. Oportunidades abertas para o Brasil face aos fluxos globais de investimento de risco e de capitais financeiros nos anos 90. Bloco: Condicionantes internacionais de competitividade. Work Shop. Campinas, 1993, $\mathrm{p}$. 62.

53. Baptista, Luiz Olavo. Investimentos internacionais no direito comparado e brasileiro - Porto Alegre: Livraria do Advogado, 1998, p. 40.

54. Montoro Filho, André Franco e outros. Manual de economia. Coordenadores: Diva Benevides Pinho, Marco Sandoval de Vasconcellos. $2^{\mathrm{a}}$ ed., São Paulo, Saraiva, 1992, p. 305. 
recursos naturais, mão-de-obra, mercados, transportes e participação do capital nacional, os aspectos financeiros são constituídos pela legislação tributária, inflação e controle do câmbio e os aspectos jurídicos pelas leis relativas aos investimentos internacionais e os tratados internacionais que estabelecem garantias e direitos ao investidor internacional. Este último aspecto será alvo do presente item.

- Conceito de investidor.

Por ocasião de qualquer relação jurídica é imperioso determinar quais são os sujeitos que podem ser objetos de direitos e obrigações. Assim, é necessário definir quem pode ser considerado como investidor internacional.

O critério utilizado pela Lei n. 4.131/62 para determinar o investidor internacional foi o da procedência: "Consideram-se capitais estrangeiros para os efeitos desta Lei, os bens, máquinas e equipamentos entrados no Brasil sem dispêndio inicial de divisas, destinados à produção de bens ou serviços, ${ }^{5 S}$ bem como os recursos financeiros ou monetários, introduzidos no País, para a aplicação de atividades econômicas, desde que, em ambas as hipóteses, pertençam a pessoas fisicas ou jurídicas residentes, domiciliadas ou com sede no exterior" 56

Assim, para a determinação do investidor estrangeiro prevaleceu a procedência do capital sobre a nacionalidade do investidor e como brilhantemente coloca o professor doutor Luiz Olavo Baptista, "melhor seria dizer investidor do estrangeiro do que investidor estrangeiro" 57

O caráter da procedência do investimento estrangeiro completa-se com as definições "residentes, domiciliadas ou com sede no exterior".

A residência e domicílio como conceito próprio das pessoas físicas têm definição no âmbito do Código Civil e do Código Tributário que estipula que o domićlío civil da pessoa natural é o lugar onde ela exerce a sua residência com

55. O Banco Central tem identificado quais são os bens, máquinas e equipamentos considerados produtivos.

56. Art. $1^{\circ}$ da Lei n. $4.131 / 62$ (grifei).

57. Baptista, Luiz Olavo. Investimentos internacionais no direito comparado e brasileiro - Porto Alegre: Livraria do Advogado, 1998, p. 64. 
ânimo definitivo habitual, ou, sendo a residência incerta ou desconhecida, o centro habitual de sua atividade. ${ }^{58}$

Com relação às pessoas jurídicas a determinação do domicílio ou sede será dada negativamente pelas definições do art. 11 da Lei de Introdução do Código Civil, art. 35, IV do Código Civil e art. 127, II do Código Tributário Nacional, ou seja: não serão consideradas pessoas jurídicas estrangeiras as empresas constituídas sob a lei brasileira e que tenham as suas sedes e administração no País.

- As exceções à isonomia específica dos capitais estrangeiros.

O conceito de isonomia disposto no art. $5^{\circ}$ da Carta Política de 1988 encontra especificidade no art. $2^{\circ}$ da Lei n. 4.131 que dispõe que "ao capital estrangeiro que se investir no País será dispensado tratamento jurídico idêntico ao concedido ao capital nacional em igualdade de condições, sendo vedadas quaisquer discriminações não-previstas na presente Lei"

O tratamento jurídico idêntico é, inclusive, ratificado pelo art. 29 da Lei n. 8.383/91, art. da Lei n. 8.981/95 e pelo art. 18 da Lei n. 9.249/95, constituindo tal princípio um mínimo de segurança para o investidor estrangeiro.

No entanto, a Constituição Federal vigente afastou ao capital estrangeiro algumas áreas de atividades econômicas como o serviço postal e o correio aéreo nacional, ${ }^{59}$ a exploração e o aproveitamento de jazidas, em lavra ou não, e demais recursos minerais, os potenciais de energia hidráulica, ${ }^{60}$ a propriedade de empresa jornalística e de radiodifusão sonora e de sons e imagens; ${ }^{61}$ ou seja: atividades privativas do Estado ou reservadas a brasileiros.

Sem entrar nos meandros doutrinários pode-se argüir que essas exceções e constituições não afetam o ponto principal do investidor estrangeiro a segurança do investimento na medida em que vedam a própria constituição do investimento.

58. Art. 131 do Código Civil combinado com o art. 121 do Código Tributário Nacional.

59. Art. 21, X da Constituição Federal

60. Art. $176, \S 1^{\circ}$ da Constituição Federal.

61. Art. 222 da Constituição Federal. 
- O registro do investimento.

O registro do investimento ${ }^{62}$ no Banco Central, representado pelo certificado de registro, ${ }^{63}$ outorga os direitos ao investidor internacional de retorno do capital, remessa de dividendos e reinvestimentos em moeda estrangeira dos lucros remissíveis.

$\mathrm{Na}$ falta do registro o Banco Central considera o valor do investimento como não-ingressado, o que acarreta ao Fisco o entendimento de que tal valor foi adquirido a custo zero, incidindo, portanto a alíquota de $15 \%$ a título de imposto de renda na fonte. ${ }^{64} \mathrm{E}$ esse é o conceito de capital contaminado.

A problemática do capital contaminado é ampla, principalmente quando os influxos se dão no âmbito das pessoas jurídicas. Quando uma empresa possui capital contaminado e não-contaminado não é possível identificar as participações que se encontram contaminadas devido ao fato da fungibilidade da moeda. ${ }^{65}$

O Banco Central entende que para que ocorra a impossibilidade de se identificar quais são as quotas ou ações que se apresentam contaminadas é necessário a contaminação de pelo menos $20 \%$ do capital social.

O procedimento para a descontaminação estabelecido pelo Banco Central que depende de autorização prévia está vinculado a um investimento de valor igual ao do capital contaminado, apurado em balanço levantado em data nãosuperior a 60 (sessenta) dias do ingresso do novo investimento.

62. Trata-se de investimentos em quaisquer das suas formas, ou seja: capitais ingressados, investimentos direitos, remessas feitas de lucros ou capital repatriado, os reinvestimentos de lucros e os decorrentes das reavaliações do capital das empresas.

63. Sobre a natureza declaratória ou constitutiva do registro do investimento ver a excelente obra citada do professor doutor Luiz Olavo Baptista.

64. Lei n. $9.249 / 95$.

65. Baptista, Luiz Olavo. Investimentos internacionais no direito comparado e brasileiro - Porto Alegre: Livraria do Advogado, 1998, p. 82. 
- Proteção jurídica do investimento.

Os riscos estão presentes em quaisquer atividades empresariais e constituem um importante fator de insegurança para o investidor e, conseqüentemente, para os influxos de capitais.

Dentre os riscos inerentes às atividades empresariais têm-se os econômicos, os financeiros e os políticos. ${ }^{66}$ À natureza dos riscos econômicos e financeiros é necessária uma análise preponderantemente econômica, já aos riscos políticos, derivados do jus imperi do governo anfitrião, as ciências jurídicas desempenham importante papel na busca de instrumentos que possam tornar-lhes mais adequados aos constantes investimentos internacionais.

Essa importância do papel jurídico acentua-se pelo fato de que os investimentos mais sensíveis aos riscos políticos são os investimentos diretos ${ }^{67}$ que justamente constituem para os países em desenvolvimento uma das mais importantes fontes para o crescimento econômico.

O papel jurídico interno e externo desenvolve-se no âmbito de definir as regras e condições relativas a expropriação direta e indireta.

$\mathrm{O}$ art. 11 da Convenção de Seul (MIGA) define expropriação e medidas assemelhadas como sendo "qualquer ação ou omissão legislativa ou administrativa atribuivel ao governo anfitrião que tenha o efeito de privar o titular de uma garantia da sua propriedade ou de seu controle, ou se um lucro substancial provindo de seu investimento - com exceção de medidas não-discriminatórias de aplicação geral que os governos normalmente adotam com a finalidade de regular as atividades econômicas em seus territórios."

- O Direito de expropriar.

A Resolução n. 1.803 de 1962 da Assembléia Geral da ONU reconheceu aos países o direito de expropriações fundadas em motivos de utilidade

66. O MIGA considera como riscos politicos àqueles referentes às transferências, expropriação e medidas assemellhadas, quebra de contrato, guerras e distúrbios.

67. Castro Helou, Christiane Costa e Silva. Proteção, tratamento e garantia dos investimentos internacionais contra os riscos politicos: aspectos de direito internacional. Dissertação de Mestrado em Direito Internacional na Faculdade de Direito da Universidade de São Paulo, 1997, p. 37. 
pública, segurança ou de interesse nacional, em contrapartida de uma indenização adequada estipulada pelos recursos judiciais internos ou pela arbitragem.

Seguindo a ordem cronológica tem-se a Carta dos Direitos e Deveres Econômicos dos Estados ${ }^{68}$ que diga-se a princípio - alterou a Resolução anterior na medida em que não estipulou que a expropriação deve-se atender o interesse social, a defesa ou a segurança nacional e prontificar uma indenização adequada, olvidando inclusive de citar como válidas as regras do Direito Internacional.

A Resolução anterior teve o apoio de quase a totalidade dos países desenvolvidos e em desenvolvimento (87 votos favoráveis contra 2 desfavoráveis, ${ }^{69}$ abstendo-se somente os países socialistas) já a Carta de 1974 teve o voto contra dos países desenvoividos, donde decorre o corolário de que a Carta de 1974 não alterou a Resolução de 62. Assim, pode-se dizer que o direito de expropriar é consagrado na ordem internacional nos casos e nas condições previstas na Resolução de $1962 .^{70}$

Com relação às atitudes expropriatórias de investimentos internacionais o Brasil não possui antecedentes ${ }^{71} \mathrm{e}$ as Constituições Federais sempre reconheceram mediante regular processo judicial o direito de propriedade e indenização em caso de desapropriação. ${ }^{72}$

No entanto, apesar das regras materiais sobre expropriação e indenização serem compatíveis com os preceitos dos países desenvolvidos, as regras instrumentais têm provocado insatisfações, já que a proteção da propriedade nem sempre é observada pelo Judiciário ${ }^{73}$ e o processo judicial para a apuração da

68. Aprovada pela Resolução n. 3.281 (XXIX) da Assembléia Geral da ONU de 1974.

69. França e África do Sul.

70. Magalhães, José Carlos de. Acordos bilaterais de promoção e proteção de investimentos. Revista Informação Legislativa - Brasilia a.34 n. 134 abr./jun. 1997, p. 14.

71. Lembre-se que o Ato Institucional n. 5 foi aplicado somente a brasileiros.

72. A Constituição Federal de 1891 impõe indenização prévia (art. 72,17); as Constituições de 1934, 1937 e 1946 prevêem a desapropriação por necessidade ou utilidade pública, mediante prévia e justa indenização (art. 113, n. 17; art. 122, n. 14; art. 141, §16; respectivamente), a de 1967 e 1969 (art. 153, $\S 22$ e 161) e a vigente, aprovada em 1988, cujo art. $5^{\circ}$ dispõe, em seu inciso XXIV; que " $a$ lei estabelecerá o procedimento para a desapropriação por necessidade ou utilidade pública, ou por interesse social, mediante justa e prévia indenização em dinheiro, ressalvados os casos previstos nesta Constituição" Magalhães, José Carlos de. Acordos bilaterais de promoção e proteção de investimentos. Revista Informação Legislativa - Brasilia a.34 n. 134 abr./jun. 1997, p. 15.

73. A exemplo a concessão liminar de imissão da posse ao Poder expropriante em caso de urgência sem o pagamento integral do valor do bem. 
quantia devida é moroso e subordinado à ordem cronológica dos precatórios. ${ }^{74}$ Por estes motivos que os tratados internacionais facultam ao investidor estrangeiro optar pela arbitragem, ${ }^{75}$ tornando-os necessários.

A preocupação atual dos investidores, em era privatizante, está mais voltada à expropriação indireta a direta (nacionalização). Assim os acordos bilaterais referem-se freqüentemente às creeping expropriation (expropriações indiretas) que são decorrentes das políticas fiscais, monetárias e aduaneiras.

A situação atual do Brasil com relação aos acordos bilaterais de promoção de investimentos é ainda conturbada, na medida em que dos acordos firmados com os EUA (1965), Alemanha (1995), Chile (1994), Coréia (1995), Dinamarca (1995), Finlândia (1996), França (1995), Grã-Bretanha (1994), Itália (1995), Portugal (1994), Suíça (1994) e Venezuela (1995), o único internacionalizado é o assiriado com os EUA.

São Paulo, dezembro de 1997.

Bibliografia.

Livros, Teses e Revistas.

Banco Central. Análise do Mercado de Câmbio - 4 Trimestre. 1997.

Banco Central. Boletim 1995.

Banco Central. Boletim 1996.

Banco Central. Boletim 1997.

Banco Central. Resenha Econômica 1997.

Banco Central. Resenha Econômica 1996.

Banco Central. Separata 1996.

74. Sobre o regime desapropriatório ver arts. $182, \S 4^{\circ}$ e 184 da CF e art. 17 da Lei Complementar n. 76/93 e art. 29 do Decreto-lei n. 3.365/41.

75. "Assim, não-obstante o regime juridico 'rasileiro assegure a indenização prévia nas despropriações, a dinâmica das administrações públicas municipais, estaduais e federal, como o beneplácito - ou conveniência do Judiciário, torna-as muitas vezes abusivas. A controvérsia do valor da indenização pode ser submetidr à arbitragem, não restando dúvida ao assunto", Revista Trimestral de Jurisprudência, v. 68, pp. 383-384 in Magalhães, José Carlos de. Acordos bilaterais de promoção e proteção de investimentos. Revista Informação Legislativa - Brasilia a.34 n. 134 abr./jun. 1997, p. 15. 
BAPTISTA, Luiz Olavo. Investimentos internacionais no direito comparado $e$ brasileiro, Porto Alegre, Livraria do Advogado, 1998.

BARROS, Octavio de. Estudo da competitividade da indústria brasileira. Oportunidades abertas para o Brasil face aos fluxos globais de investimento de risco e de capitais financeiros nos anos 90. Bloco Condicionantes internacionais de competitividade. Work Shop, Campinas, 1993.

BNDES/ Privatização. Moedas. http://bndes.gov.br/moedas.html.

CASSEB, Norma Cristina Brasil. Perfil dos investimentos e distribuição de renda na economia brasileira (1970-1993). Tese apresentada ao Departamento de Economia da Faculdade de Economia, Administração e Contabilidade da Universidade de São Paulo, 1995.

CASTRO Helou, Christiane Costa e Silva. Proteção, tratamento e garantia dos investimentos internacionais contra os riscos políticos: aspectos de Direito Internacional. Dissertação de Mestrado em Direito Internacional na FDUSP. 1997.

DALLARI, Pedro Bohomoletz de Abreu. Princípios de relações exteriores na Constituição brasileira de 1988. Dissertação de mestrado apresentada à FDUSP, 1992.

ESTADO DE S. PAULO de 05.09.93.

FIRCE. Suplemento Estatístico, dezembro 1997.

Formulation and implementation of foreign investment policies: selected key issues, 1992.

FORTUNA, Eduardo. Mercado financeiro: produtos e serviços - São Paulo: Qualitymark Editora, 10ª ed., 1997.

International Factor Movements.

JASPERSEN, Frederick Z. Retorno de capitais para a América Latina. rev. A Região, seção investimentos. 1992.

KANDIR, Antonio. Resposta do Brasil à crise, http://www.seplan.gov.br/Artigos/a resposta.htm.

MAGALHÃES, José Carlos de. Acordos bilaterais de promoção e proteção de investimentos. Revista Informação Legislativa, Brasília, 34 n. 134 abr./jun. 1997.

MOISÉS, Cláudia Perrone. Direito ao desenvolvimento e investimentos estrangeiros. Tese de doutoramento apresentada ao Departamento de Direito Internacional da FDUSP, 1997. 
MONTORO FILHO, André Franco e outros. Manual de economia. Coordenadores: Diva Benevides Pinho, Marco Sandoval de Vasconcellos. $2^{a}$ ed., São Paulo: Saraiva, 1992.

NOVAIS, Marcelo. Dinheiro a vapor. Dicas de Negócios, Oesp Mídia Direta, RPM $\mathrm{Html}$. ano 1 , n. 7. http://www.listas-amarelas.com.br/oesp/revista/rpm1796/dicas.

PELLEGRINI, Josué A., Os fluxos recentes de capital para a América Latina, tese de Doutorado apresentada na Universidade de São Paulo, 1995.

VERNON, Raymond. Research on transnational corporations: shedding old paradigms. Transnational Corporation, v. 3, n. 1, fev. 1994.

WORLD INVESTMENT REPORT 1994. Transnational Corporations, Employment and the Workplace. United Nations. New York and Geneva, 1994.

Normas.

Banco Central. Resolução n. 1.289.

Banco Central. Resolução n. 1.806.

Banco Central. Resolução n. 1.832.

Banco Central. Resolução n. 1.927

Banco Central. Resolução n. 2.034.

Banco Central. Resolução n. 2.247

Banco Central. Resolução n. 2.344.

Código Civil.

Código Tributário Nacional.

Constituição Federal de 1988.

Instrução CVM n. 175 de 06.02.92.

Instrução CVM n. 205 de 14.01.94.

Instrução CVM n. 209 de 25.03.94.

Instrução CVM n. 222 de 21.10.94.

Lei n. 4.131/62.

Lei n. 8.031/90.

Lei n. 9.249/95. 